Review

\title{
Should we reconsider the apoptosis as a strategic player in tissue regeneration?
}

\author{
Bruna Codispoti ${ }^{1}$, Irina Makeeva ${ }^{2}$, Jamal Sied ${ }^{3}$, Caterina Benincasa ${ }^{1}$, Salvatore Scacco ${ }^{4 \#}$, Marco Tatullo ${ }^{1,2}{ }^{\boxplus}$ \\ 1. Marrelli Health, Tecnologica Research Institute, Biomedical Section, Street E. Fermi, Crotone, Italy \\ 2. Department of Therapeutic Dentistry, IM Sechenov First Moscow State Medical University, Moscow, Russia \\ 3. Advanced Technology Dental Research Laboratory, Faculty of Dentistry, King Abdul Aziz University, KSA and Director of CODE-M, Center of Dental \\ Education and Medicine, Pakistan \\ 4. Dept. of Basic Medical Sciences, Neurosciences and Sense Organs, University of Bari, Italy \\ \#These authors equally contributed to this article
}

$\square$ Corresponding author: Prof. Marco Tatullo, Scientific Director - Tecnologica Research Institute, St. E. Fermi - Crotone, Italy. Professor of "Regenerative Medicine" - IM Sechenov First Moscow State Medical University. E-mail: marco.tatullo@tecnologicasrl.com

(c) The author(s). This is an open access article distributed under the terms of the Creative Commons Attribution License (https://creativecommons.org/licenses/by/4.0/). See http://ivyspring.com/terms for full terms and conditions.

Received: 2019.05.05; Accepted: 2019.06.19; Published: 2019.07.25

\begin{abstract}
Apoptosis plays a central role in organs development and homeostasis. Impaired regulation of this process is often associated with the onset of several human diseases, such as developmental disorders and cancer. The last scientific investigations have discovered interesting connections between apoptosis, stem cells, tissue regeneration and cancer. The role of "programmed cell death" in stem cells and tissue engineering is extremely promising; in fact, it holds great potential for regenerative purposes. However, several questions still remain unsolved: do we really know all the main molecular actors able to switch ON/OFF the apoptosis? Is it possible to modulate these players, to obtain a predictable regeneration of tissues and organs? But primarily: should we reconsider the apoptosis as a strategic player in tissue regeneration? In this topical review, we have carefully examined the most recent discoveries about the role of apoptosis in stem cells and, specifically, in mesenchymal stem cells. The pivotal molecules involved in the activation and inhibition of the apoptotic pathways will be carefully described, with the aim to shed an overall light on the complex scenario of stem cell life and death, and on a novel strategy for tissue regeneration.
\end{abstract}

Key words: Apoptosis, Regenerative Medicine, Mesenchymal Stem Cells, Cell Death

\section{Introduction}

Apoptosis plays a central role in organs development and homeostasis. Impaired regulation of this process is often associated with the onset of several human diseases, such as developmental disorders and cancer [1-3]. In recent years, the scientific community has investigated on apoptosis, because of interesting connections between apoptosis, stem cells, tissue regeneration and cancer. It is clear that apoptosis plays a central role in organs development and homeostasis: in this light, the molecules and the cell organelles involved in the activation and inhibition of the apoptotic pathways have been carefully described in the scientific literature, however, some aspects still remain unclear
[4]. In this scenario, mitochondria have been demonstrated to have a central role in the apoptotic pathways. Bcl-2 proteins regulate the release of specific molecules in the mitochondrial intermembrane space; subsequently, these proteins migrate to the cytosol, where they activate the caspase cascade. The involvement of mitochondria is essential in the "intrinsic apoptotic pathway", also called "mitochondrial pathway"; in fact, in the mitochondria, the anti-apoptotic and pro-apoptotic processes interact and trigger the release of molecular signals able to activate the cytosolic caspases [5]. These organelles can move the cytochrome-c into the cytosol, thus promoting the assembling of the 
apoptosome; this multiprotein complex stimulates the activation of caspase- 9 from procaspase- 9 , that is able to cleave the caspase-3, thus resulting in cell apoptosis [6]. In the extrinsic pathway, the starting signal is obtained through the close interaction among the ligands with the "death receptors", a group of proteins belonging to the "tumor necrosis factor" (TNF) receptor family. Upon such binding, the death-inducing signaling complex (DISC) is created, and it can induce the activation of caspase- 8 , that consequently cleave also the caspase- 3 , thus leading to the apoptosis [7].

Apoptotic cells undergo segmentation of the nucleus and alteration of their membrane, with a consequent formation of the so-called "apoptotic bodies", typically phagocytized by immune or surrounding cells [8].

The scientific discussion on the role of apoptosis in tissue regeneration can be considered as a relatively novel topic; on the other hand, the role of mesenchymal stem cells (MSCs) in regenerative procedures have been widely demonstrated. MSCs have been isolated from many human tissues, and they promise useful applications in different pathological conditions. MSCs have the ability to differentiate into the three classical mesenchymal lineages: adipogenic, osteogenic and chondrogenic [9]; however, several researches reported the interesting ability of such cells to be also differentiated toward several other cell types, including neurogenic and cardiogenic phenotypes.

MSCs express the surface markers CD73, CD90, and CD105, but they lack the expression of CD34, CD45, and HLA-DR hematopoietic antigens. After their first discovering in human bone marrow, MSCs have been isolated from several other tissues, including adipose tissue, fetal structures as umbilical cord and, placenta, and the oral cavity $[10,11]$.

The potential of MSCs to differentiate into osteoblasts have been exploited for bone regeneration [12]. There are enough pieces of evidence that highlight how MSCs can differentiate into a large variety of other mature cells [13]: this fact stimulated the worldwide researchers to speculate a promising role for MSCs in human regenerative therapy. Furthermore, these cells play a strategic role in the local immunomodulation, useful for counteracting adverse immunologic reactions after transplantation of tissues and organs [14].

In the last years, MSCs have been used in clinical trials targeting the regeneration of damaged tissues, as well as in the treatment of several pathologies, such as multiple sclerosis (MS), Crohn's disease, diabetes and graft-versus-host disease (GVHD). Numerous clinical trials are ongoing, to better understand the different aspects related to efficacy and safety of MSCs for clinical use [15].

In this topical review, we have carefully examined the most recent discoveries about the role of apoptosis in stem cells and, specifically, in mesenchymal stem cells. The pivotal molecules involved in the activation and inhibition of the apoptotic pathways will be carefully described, to shed an overall light on the complex scenario of stem cell life and death, and on a novel strategy for tissue regeneration.

A literature searching strategy has been used to select the papers to be included in this review. The most used searching engines, such as Medline and Google Scholar has been used by searching for the following keywords: "Apoptosis AND Regeneration", "Apoptosis AND Stem Cells", "Apoptosis AND MSCs", "Apoptosis AND Disease" and "Apoptosis AND Tissue repair". The authors have carefully revised the title, the abstract, and the main text for each of the selected papers. Finally, the papers specifically correlated to our aim were included in this review.

\section{Apoptosis in pathology and tissue repair}

Based on the central role of apoptosis in maintaining the body homeostasis, it is not surprising that specific alterations of this process may lead to several pathological conditions. Numerous diseases are related to a massive cell death, which determines severe damages with severe consequences for patients' health. In liver failure induced by drugs or alcohol, viral infections, stroke, heart infarction, and cachexia [16-19], a general cell loss typically occurs and certainly may contribute to the increase of patient mortality [20].

In cancer pathogenesis, several alterations of different proteins involved in apoptotic pathways, including the Bcl-2 Family proteins, the death receptor, the apoptosome, and the aberrant caspase activity, are commonly found in neoplastic cells. The mutation of p53 gene, which is fundamental in activating programmed cell death in response to different stimuli, represents the major alteration found in the human tumors: this is indicative about the importance of apoptosis in neoplastic transformation.

Degenerative disease of the brain, including Alzheimer's disease [21], Parkinson's disease [22] and amyotrophic lateral sclerosis [23] could exert an involvement of caspase proteins in their pathogenesis. Moreover, autoimmune diseases, such as systemic lupus erythematosus and the autoimmune lymphoproliferative syndrome, may depend on alteration of immune homeostasis and maintenance of 
immune tolerance that are strongly related to apoptosis [24].

Interesting studies have pointed out the central role of apoptosis in tissue repair [25]. Wound healing is a multistep process, consisting of different phases: in a first step, the open wound triggers an intense inflammatory response, able to protect the biological site against the external microorganisms; furthermore, several inflammatory cells, such as neutrophils and macrophage, typically produce cytokines, chemokines and growth factors that stimulate the migration and the proliferation of fibroblast cells [25]. When the inflammatory response declines, this new phase is characterized by the proliferation of collagenproducing cells, and by the contemporary disappearing of inflammatory cells after massive apoptosis [26].

Experimental studies reported that apoptosis occurring within the inflammatory phase of wound healing could be mediated by specific cytokines, such as tumor necrosis factor- $\alpha$ and interleukin-1, released from immune cells: these mediators promote a local response that activates the programmed cell death [27]. Alternatively, the apoptosis of inflammatory cells could be p53-mediated [28]. During the proliferative phase of tissue repair, fibroblasts exert their function of collagen deposition, on the other hand, in the last phase of wound maturation, fibroblasts, and residual endothelial cells undergo apoptosis [29].

Some in vitro researches propose that apoptosis of fibroblasts and vascular cells could be induced by c-myc, that promotes the interaction of fas and Fas-ligand on cell membranes [30]; on the other side, the interferons could mediate apoptotic pathway activation [31].

Numerous animal models have clarified the complex apoptotic mechanisms, including the wide range of molecular elements involved and the multitude of pathways implicated. Apoptosis was first characterized in C. Elegans; in a second stage, different biological systems, including Drosophila and mammals, allowed further investigations [32]. Currently, mathematical models and single-cell analysis represent innovative tools for a better understanding of the complex mechanisms of cell death [33].

\section{Apoptosis and regeneration}

The programmed cell death has a remarkable significance in regulating the correct cell replication in damaged tissue. Worldwide labs have been increasingly involved in research programs aimed to clarify the intriguing role of apoptosis in stem cell function during tissue regeneration (Table 1).
The importance of the apoptotic pathways is particularly interesting in the gastrointestinal tract: in fact, a limited number of stem cells cyclically undergo apoptosis because of a mechanism controlled by a p53-independent way. On the other hand, in response to genotoxic stimuli, stem cells residing in the gastrointestinal duct undergo p53-dependent apoptosis. This different regulation pathway could partially explain the lower prevalence of cancer in such tissues with high-rate cell turn-over [1]. In the intestinal epithelium, the high-rate cell division is controlled by the Wnt-signalling that typically promotes the self-renewal ability of MSCs; however, the MSC self-renewal should be balanced with an analog rate of apoptosis, and the molecular mechanisms deputed to regulate such process involve the pro-apoptotic protein ARTS. ARTS protein is an atypical mitochondrial protein able to modulate TGF-beta-induced apoptosis and to induce cell killing by several pro-apoptotic factors: when ARTS protein is deactivated, this can preserve the intestinal cells from apoptosis, and, on the other hand, this can promote the in-vitro formation of complex organoids through the activation of specific Wnt-signalling.

During the MSC apoptosis, ARTS protein is activated, and it passes from the mitochondria to the cytoplasm: there, ARTS blocks XIAP, a potent apoptosis inhibitor. In recent studies, mice models deficient for ARTS expression showed significant resistance against intestinal tissue damage, and those animals showed improved tissue regeneration, mainly mediated by the blocking of XIAP [34]. Fuchs et al. showed that mice lacking the Sept4/ARTS gene showed higher levels of hair follicle stem cells. Surprisingly, mice lacking the Sept4/ARTS gene exhibited also a significant enhancement in wound healing ability and in hair follicle regeneration. The inhibition of the target-protein for ARTS reverted these phenomena and reduced the previously observed wound healing. The main results reported in several international studies on ARTS-mediated apoptosis have clearly indicated that the previously described pathways could represent a promising tool, able to improve tissue repairing and wound healing [35].

Apoptosis occurring during the tissue development involves at the same time entire clusters of cells, in order to ensure proper growth of immature tissues; in this context, we can report as an example what commonly happens during the catagenic-phase of the hair follicles. The "cluster apoptosis" is regulated by a feedback mechanism, called "apoptosis-induced-apoptosis" (AIA) [36]. During this biological process, the first cells undergo apoptosis release specific molecular signals, such as those 
belonging to TNF family, to the surrounding cells: these cells are thus induced to follow the same fate, undergoing apoptosis too. The starting apoptosis signaling is supposed to be amplified through the activation of the c-Jun N-terminal kinase (JNK) pathway [37]. In the first studies, AIA was extensively studied in Drosophila model, and the following investigations further described this biological phenomenon also in mammals. In humans, AIA takes place during the development of the tissues and under specific pathological conditions, such as the wide cell death associated with strokes [38].

Table 1: Experimental evidences of the main apoptotic events

\begin{tabular}{|c|c|c|c|c|}
\hline Apoptotic events & Experimental systems & Molecular mechanisms & $\begin{array}{l}\text { Induced } \\
\text { effects }\end{array}$ & References \\
\hline $\begin{array}{l}\text { p53-dependent } \\
\text { apoptosis }\end{array}$ & $\begin{array}{l}\text { In vivo: cells of the } \\
\text { gastrontestinal tract }\end{array}$ & p-53 protein activation & Control of stem cell proliferation & $\begin{array}{l}\text { Potten. Oral Dis } \\
\text { (2001) }\end{array}$ \\
\hline \multirow[t]{2}{*}{ Apoptosis } & $\begin{array}{l}\text { In vitro: } \\
\text { Sept } 4 \text { / ARTS-/- crypt cells }\end{array}$ & $\begin{array}{l}\text { Activation of } \\
\text { ARTS by induction of Wnt } \\
\text { signalling and block of XIAP }\end{array}$ & $\begin{array}{l}\text { ART protects intestinal cells from apoptosis, increments } \\
\text { cell proliferation and produces organoids, in vitro }\end{array}$ & $\begin{array}{l}\text { Koren et al. } \\
\text { Nat Commun (2018) }\end{array}$ \\
\hline & In vivo: Sept4/ARTS-/- mice & $\begin{array}{l}\text { ARTS mediates apoptosis } \\
\text { independently of Wnt signaling }\end{array}$ & $\begin{array}{l}\text { ARTS loss protects mice from formation of cysts and } \\
\text { inflammatory colitis }\end{array}$ & \\
\hline Apoptosis & $\begin{array}{l}\text { In vivo: } \\
\text { Sept } 4 \text { /ARTS- - mice }\end{array}$ & ARTS inactives XIAP & $\begin{array}{l}\text { ARTS has the ability to heal wounds and regenerate the } \\
\text { hair follicle by regulation of stem cell regeneration }\end{array}$ & $\begin{array}{l}\text { Fuchs et al. } \\
\text { Science (2018) }\end{array}$ \\
\hline \multirow[t]{3}{*}{$\begin{array}{l}\text { Apoptosis-Induced-Ap } \\
\text { optosis (AIA) }\end{array}$} & In vivo: & & & $\begin{array}{l}\text { Perez-Garijo et al. } \\
\text { Elife (2013) }\end{array}$ \\
\hline & -Drosophila & Activation of the JNK pathway & Cell death in a non-autonomous way & \\
\hline & -Mice & TNF molecular signal & $\begin{array}{l}\text { The cells that first take the path of apoptosis induce the } \\
\text { surrounding cells to apoptosis }\end{array}$ & \\
\hline $\begin{array}{l}\text { Apoptosis-induced } \\
\text { compensatory } \\
\text { proliferation (AIP) }\end{array}$ & $\begin{array}{l}\text { In vivo: } \\
\text { Drosophila melanogaster }\end{array}$ & $\begin{array}{l}\text { Activaction of } \\
\text { Orthologue protein of WNT } \\
\text { BMPs and EGF }\end{array}$ & $\begin{array}{l}\text { Apoptotic cells produce mitogenic signals that trigger } \\
\text { compensatory proliferation }\end{array}$ & $\begin{array}{l}\text { Fan. et al. } \\
\text { PLoS Genet (2014) }\end{array}$ \\
\hline $\begin{array}{l}\text { Apoptosis-induced } \\
\text { compensatory } \\
\text { proliferation (AIP) }\end{array}$ & $\begin{array}{l}\text { In vivo: } \\
\text { Drosophila melanogaster }\end{array}$ & $\begin{array}{l}\text { Activation of the Jun N-terminal } \\
\text { kinase and p } 53 \text { mediated signal } \\
\text { through the initial caspase } \\
\text { Dronc. ROS formation }\end{array}$ & $\begin{array}{l}\text { Decapentaplegic and Wingless mitogens are induced and } \\
\text { trigger compensatory proliferation in surrounding cells } \\
\text { and the recruitment of immune cells on the site of injury }\end{array}$ & $\begin{array}{l}\text { Fan et al. } \\
\text { Trends Cell Biol (2008) }\end{array}$ \\
\hline $\begin{array}{l}\text { Apoptosis-induced } \\
\text { compensatory } \\
\text { proliferation (AIP) }\end{array}$ & $\begin{array}{l}\text { In vivo: } \\
\text { Xenopus tadpole }\end{array}$ & $\begin{array}{l}\text { ROS activate Wnt } / \beta \text {-catenin and } \\
\text { FGF signalling }\end{array}$ & $\begin{array}{l}\text { The signal produces the activation of numerous } \\
\text { pathways, including the Wnt, Fgf, BMP, notch, and TGF } \beta \\
\text { pathways, that induce cell proliferation }\end{array}$ & $\begin{array}{l}\text { Love et al. } \\
\text { Nat Cell Biol (2013) }\end{array}$ \\
\hline $\begin{array}{l}\text { Apoptosis-induced } \\
\text { compensatory } \\
\text { proliferation (AIP) }\end{array}$ & $\begin{array}{l}\text { In vivo: } \\
\text { Hydra }\end{array}$ & ROS activate Wnt3 & $\begin{array}{l}\text { WNT activates } \beta \text {-catenin and induces proliferation of } \\
\text { surrounding cells }\end{array}$ & $\begin{array}{l}\text { Chera et al. } \\
\text { Dev Cell (2009) }\end{array}$ \\
\hline $\begin{array}{l}\text { Apoptosis and } \\
\text { regeneration }\end{array}$ & $\begin{array}{l}\text { In vitro: } \\
\text { MSCs }\end{array}$ & $\begin{array}{l}\text { Activation of p38 and JNK } \\
\text { signalling }\end{array}$ & $\begin{array}{l}\text { P38 initiates cell-death pathways that lead to early } \\
\text { apoptosis; JNK activation, instead, is involved in the late } \\
\text { apoptosis }\end{array}$ & $\begin{array}{l}\text { Wei et al. } \\
\text { J Cell Biochem (2010) }\end{array}$ \\
\hline \multirow[t]{2}{*}{$\begin{array}{l}\text { Apoptosis and } \\
\text { regeneration }\end{array}$} & $\begin{array}{l}\text { In vitro: } \\
\text { MSCs }\end{array}$ & Caspase 3 activation & $\begin{array}{l}\text { Caspase- } 3 \text { alters signal transduction by limiting activation } \\
\text { of the Ras-Raf-MEK-ERK pathway, the lack of caspase } 3 \\
\text { reduces the differentiation in neurons }\end{array}$ & $\begin{array}{l}\text { Janzen et al. } \\
\text { Cell Stem Cell } \\
(2005)\end{array}$ \\
\hline & $\begin{array}{l}\text { In vivo: } \\
\text { Mice }\end{array}$ & Caspase 3 deletion & $\begin{array}{l}\text { The lack of the caspase- } 3 \text { effector in mice increases the } \\
\text { proliferation of hematopoietic stem cells and slows their } \\
\text { maturation }\end{array}$ & \\
\hline $\begin{array}{l}\text { Apoptosis and } \\
\text { regeneration }\end{array}$ & $\begin{array}{l}\text { In vitro: } \\
\text { Embryonic stem cells }\end{array}$ & Espression of Caspase 3 & $\begin{array}{l}\text { Induce differentiation by down-regulation of Nanog } \\
\text { signalling }\end{array}$ & $\begin{array}{l}\text { Fujita et al. } \\
\text { Cell Stem Cell (2008) }\end{array}$ \\
\hline $\begin{array}{l}\text { Apoptosis and } \\
\text { regeneration }\end{array}$ & $\begin{array}{l}\text { In vivo: } \\
\text { (Casp3(-/-) and Casp3(+/-)) } \\
\text { mice }\end{array}$ & $\begin{array}{l}\text { The overactivated } \\
\text { TGF-beta/Smad } 2 \text { signalling } \\
\text { pathway and the upregulated } \\
\text { expressions of p53 and p21 }\end{array}$ & $\begin{array}{l}\text { The shortage of Caspase } 3 \text { retards ossification and } \\
\text { reduced bone mineral density }\end{array}$ & $\begin{array}{l}\text { Miura et al. } \\
\text { J Clin Invest (2004) }\end{array}$ \\
\hline $\begin{array}{l}\text { Apoptosis and } \\
\text { regeneration }\end{array}$ & $\begin{array}{l}\text { In vitro: } \\
\text { Sebaceous gland cells }\end{array}$ & $\begin{array}{l}\text { Caspase- } 3 \text { induces the } \\
\text { translocation of YAP protein }\end{array}$ & $\begin{array}{l}\text { Caspase- } 3 \text { activation leads to an increase in the size of the } \\
\text { YAP-dependent organ; } \\
\text { Caspase- } 3 \text { inhibition reduces cell proliferation and } \\
\text { sebaceous gland dimension }\end{array}$ & $\begin{array}{l}\text { Yosefzon et al. } \\
\text { Mol Cell (2018) }\end{array}$ \\
\hline Apoptosis & $\begin{array}{l}\text { In vivo: } \\
\text { GVHD mouse model }\end{array}$ & Infusion of apoptotic MSCs & $\begin{array}{l}\text { Immunomodulation } \\
\text { by indoleamine 2,3-dioxygenase released by phagocytes }\end{array}$ & $\begin{array}{l}\text { Galleu et al. } \\
\text { Sci Tran Med (2017) }\end{array}$ \\
\hline Apoptosis & $\begin{array}{l}\text { In vitro: } \\
\text { Apoptotic bodies (ApoEVs) }\end{array}$ & Infusion of ApoEVs & Regulation of immune response & $\begin{array}{l}\text { Codispoti et al. } \\
\text { J Clin Med (2018) }\end{array}$ \\
\hline Apoptosis & $\begin{array}{l}\text { In vivo: } \\
\text { Fas-deficient } \\
\text { MRL/lpr and Caspase } \\
3^{-/-} \text {mice }\end{array}$ & Activation of Wnt pathway & $\begin{array}{l}\text { Engulfment of exogenous apoptotic bodies by recipient } \\
\text { MSCs, that reuse molecular inhibitor of Axin finally } \\
\text { resulting in activation of Wnt pathway and self-renewal } \\
\text { initiation }\end{array}$ & $\begin{array}{l}\text { Liu et al. } \\
\text { Cell Res (2018) }\end{array}$ \\
\hline Apoptosis & $\begin{array}{l}\text { In vitro: } \\
\text { human bone marrow-derived } \\
\text { MSCs }\end{array}$ & Non-adherent culture conditions & $\begin{array}{l}\text { Removal from adherent culture contributes to apoptosis } \\
\text { in human bone marrow mesenchymal stem cells }\end{array}$ & $\begin{array}{l}\text { Deng et al. } \\
\text { Mol Med Rep (2017) }\end{array}$ \\
\hline Apoptosis & $\begin{array}{l}\text { In vivo: } \\
\text { Zebrafish }\end{array}$ & Activation of TNF- pathway & $\begin{array}{l}\text { TNFa/TNFR1 signalling pathway is required for the fin } \\
\text { regeneration }\end{array}$ & $\begin{array}{l}\text { Nguyen-Chi et al. } \\
\text { Cell Death Dis (2017) }\end{array}$ \\
\hline
\end{tabular}


The tissue regeneration that occurs after any traumatic wound, typically consists of a proliferative reply by local cells, in order to replace the damaged tissue; this physiologic mechanism is called "compensatory proliferation". Apoptotic cells produce mitogenic signals able to trigger this compensatory proliferation: this pivotal biological mechanism is called "apoptosis-induced compensatory proliferation" (AIP). Apoptosis-induced proliferation is an advantageous process for the organism, as it permits the elimination of damaged cells that could develop genetic mutations or cancer. Furthermore, AIP allows replacing those atypical cells with a new progeny of healthy cells. Alterations of this compensatory process may potentially result as pathological for the body [39].

AIP has been first discovered in the study-model Drosophila melanogaster; several studies have confirmed that apoptotic cells can secrete different mitogenic signals, able to trigger the cell mitosis of neighboring cells [40].

Pro-apoptotic signals can also induce the production of reactive oxygen species (ROS), that have been demonstrated to be essentials for an effective wound healing and the local recruitment of immune cells at the site of injury [41].

In Xenopus tadpole, tail amputation induces a profuse production of ROS; these amputation-induced ROS can activate the Wnt/ $\beta$-catenin and FGF signaling, and this starts an active tissue regeneration [42].

Hydra is also able to regenerate any part of its body. Following a surgically created trauma, this polyp rapidly regenerates its head, and it undoubtedly seems to be promoted by massive apoptosis. In some tissues of hydra, on the other hand, the apoptosis is very limited: consequently, the tissue regeneration is markedly slower. Forced induction of apoptosis also in the foot-related tissues fatally promotes the rapid formation of a second head. Conversely, the inhibition of the apoptosis blocks any regrowth of amputated organs. These impressive examples about the apoptosis in different animal models are strongly suggestive about the strategic role of the releasing of WNT3 signal by apoptotic cells: this is the main engine that induces tissue regeneration [43].

Oxidative stress is a well-known trigger for different pathological conditions [44,45], ROS have also a central role in the apoptosis induction. The pathways involved in the apoptotic mechanism of MSCs have been widely investigated during experimental assays with $\mathrm{H} 2 \mathrm{O} 2$ : hydrogen peroxide is a quite common exogenous oxidative stress model for MSCs, because of the good chemical properties showed by $\mathrm{H} 2 \mathrm{O} 2$, such as the good solubility in aqueous and non-aqueous solutions and its extensive half-life [46].

The administration of $\mathrm{H} 2 \mathrm{O} 2$ promotes apoptosis in MSCs, in a time- and dose-dependent manner. This treatment is able to induce the activation of p38 and JNK signaling, however, it does not affect the ERK1/2 - MAPK pathway and the death receptor signaling. To better describe these molecules: the P38 can start the mitochondrial cell death pathway and the ER-initiated (endoplasmic reticulum-initiated) cell death pathways, that lead to early apoptosis; the JNK activation, instead, is involved in the late apoptosis [47].

\section{Apoptosis and stem cells}

Current studies focused on tissue regeneration are based on the application of alternative techniques: some interesting ones are the using of Platelet-Rich Fibrin (PRF) for the management of uncommon inflammatory diseases [48], and the application of useful prosthetic devices for patients' rehabilitation $[49$, 50]. Furthermore, recent efforts allowed to monitoring the healing processes by alternative techniques of analysis [51]. On the other hand, several studies also confirmed the enormous potential of stem cell therapy in regenerative medicine.

Apoptosis-related caspases are involved in the differentiation and growing of stem cells.

Deficiency of the effector caspase 3 in mice, increases the proliferation of hematopoietic stem cells and delays their differentiation; furthermore, in primarily derived neural stem cells showing a lacking of caspase 3, it reduces the physiological differentiation into neurons [52].

In embryonic stem cells, the overexpression of caspase 3 induces their differentiation by down-regulation of Nanog signaling; Nanog is a well-known target of caspase 3, and the expression of a cleavage-resistant form of Nanog has been demonstrated in self-renewal increasing of embryonic stem cells [53]. Caspase-3-deficient mice showed a retarded ossification and a reduced bone mineral density. Bone marrow-derived MSCs from mutant mice displayed a deficit in osteogenic differentiation that could be partially explained by the detected over-activation of the TGF-beta/Smad2 pathway [54].

Caspase 3 is also involved in cell proliferation and the regulation of organs size.

In sebaceous glands, the proliferating cells may express activated caspase 3 without any sign of apoptosis. The caspase 3 induces nuclear translocation of the central regulator protein of organ size: the Yes-associated protein; thus, caspase 3 inhibition reduces cell proliferation and sebaceous gland 
dimension [55].

Apoptosis is also involved in the MSC-mediated immunomodulation in transplants. In a mouse model of graft-versus-host disease (GVHD), the infusion of apoptotic MSCs activates phagocytic cells that produce the immunosuppressive mediator indoleamine 2,3-dioxygenase, after the incorporation of injected apoptotic cells [56]. This in vivo evidence, underlines that also the in vitro induction of apoptosis, mediated by caspase 3 activation, could represent a valuable tool for the rapid down-regulation of the immune response in GVHD patients. Furthermore, several studies have supported the concept that host cytotoxic cells can induce apoptosis of injected MSCs: this allows that transplanted MSCs does not engraft into host recipient site, although they may continue to act with their immunomodulatory activity.

Apoptotic bodies are atypical extracellular vesicles produced by dying cells (ApoEVs): we previously described the ability of ApoEVs, derived from MSCs, to modulate the immune response in autoimmune conditions, in antitumor immunity and infective diseases [57].

Exogenous transplanted apoptotic bodies have been demonstrated to promote the MSCs proliferation and the osteogenic and adipogenic differentiation. The basal mechanism reported by the researchers was related to the activity of exogenous apoptotic bodies, strategically able to reuse the molecular inhibitor of Axin, finally resulting in the activation of the WNT-pathway and the self-renewal initiation [58].

In conclusion, the apoptosis of MSCs could be generally started by a severe alteration of the stem cell niche and after local damage, and the apoptosis can be enhanced by the activation of caspase 3-related pathway [59].

\section{Conclusions and future insights}

Nowadays, cell therapy often requires in vitro cell manipulation and cell expansion [60] to obtain an adequate number of cells to ensure successful transplantation in the recipient site. On the other hand, any stem cell transplantation should be carefully monitored because of their moderate risk to observe aberrations and preneoplastic transformations. Injuries and cancers, in fact, share common molecular mechanisms; fatally, stem cells are involved in both tissues repairing and tumors pathogenesis phenomena. Anti-apoptotic proteins are, on the other side, deeply correlated with stem cells survival [61].

Lastly, the discovery that dying cells exert an incredible regenerative potential has increasingly stimulated scientific research to better understand the fascinating cellular and molecular mechanisms of programmed cell death and of tissue regeneration [62].

Although AIP could seem to represent a valuable tool for regenerative medicine, it may be certainly considered as a double-edged sword, because of the potential induction of tumors in in-vivo models. Radiotherapy and chemotherapy are able to eradicate tumor-related cells by triggering their death; however, such dying cells might undergo AIP, and thus they can produce mitogenic stimuli that might contribute to metastasis and relapses of primary tumors [63].

On the other hand, the complex mechanism of AIA could be, at least partially, responsible for the bystander effect, where non-irradiated cells dye, just like the tumors cells [64].

Some interesting studies have recently linked the two mechanisms AIA and AIP; in fact, they seem to be opposed pathways, but they indeed work in close correlation, thus demonstrating that apoptosis is a mechanism more complex than we are commonly used to know. It would seem that AIA works to increase the apoptotic cells and that these cells consequently produce mitogenic signals able to induce stronger cell proliferation [65] (Figure 1).

In this review, we tried to shed light on the key molecular mechanisms that promote and/or block apoptotic pathways, describing the studies carried out on animal models that have illustrated the correlation among apoptosis and WNT, JNK p53, p38 pathways, often mediated by the recently discovered ARTS and XIAP proteins; these peptides are able to switch $\mathrm{ON} / \mathrm{OFF}$ apoptosis, in order to regulate the tissue development and regeneration. The provided experimental evidence could be potentially exploited in a clinical scenario, in order to suggest a predictable regeneration of tissues and organs by manipulating of the apoptotic process.

The everchanging knowledge of cell biology still remains largely obscure; however, we can take into account that an indissoluble link between cell apoptosis and tissue regeneration do exist, and it has been consistently confirmed in the last years. This extremely interesting correlation between apoptosis and regeneration seems to suggest different landscapes from the old theory about the role of apoptosis as a process only aimed at cell death, thus considering this biological process as a pivotal player for tissue regeneration and organs homeostasis.

\section{Competing Interests}

The authors have declared that no competing interest exists. 


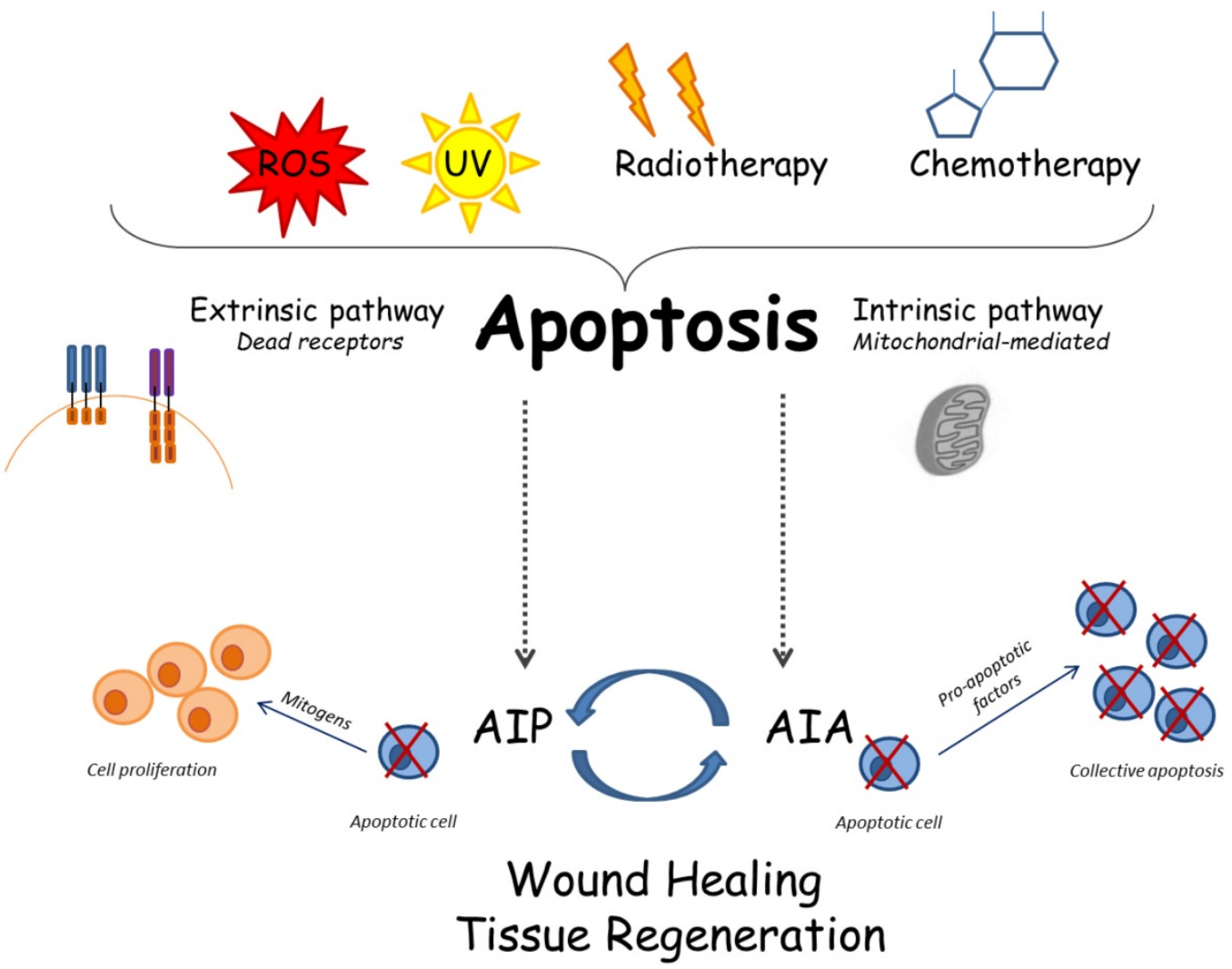

Figure 1. Cellular and molecular apoptotic mechanisms: several stimuli can trigger apoptosis; consequently, the apoptosis may follow the intrinsic or the extrinsic way. The recently described mechanisms called AIP and AIA may be involved in complex interactions among apoptosis and tissue regeneration.

\section{References}

1. Potten CS. Apoptosis in oral mucosa: Lessons from the crypt. A commentary. Oral Dis 2001; 7: 81-85.

2. Fulda S, Debatin KM. Extrinsic versus intrinsic apoptosis pathways in anticancer chemotherapy. Oncogene 2006; 25: 4798-4811.

3. Shi Y. Caspase activation, inhibition, and reactivation: A mechanistic view. Protein Sci 2004; 13: 1979-1987.

4. Feinstein-Rotkopf Y, Arama E. Can't live without them, can live with them: Roles of caspases during vital cellular processes. Apoptosis 2009; 14: 980-995.

5. Wang C, Youle RJ. The role of mitochondria in apoptosis*. Annu Rev Genet 2009; 43: 95-118.

6. Brentnall M, Rodriguez-Menocal L, De Guevara RL, et al. Caspase-9, caspase-3 and caspase-7 have distinct roles during intrinsic apoptosis. BMC Cell Biol 2013; $14: 32$

7. Gupta S, Kass GE, Szegezdi E, et al. The mitochondrial death pathway: A promising therapeutic target in diseases. J Cell Mol Med 2009; 13: 1004-1033.

8. Hengartner MO. The biochemistry of apoptosis. Nature 2000; 407: 770-776.

9. Chiarella E, Aloisio A, Codispoti B, et al. Znf521 has an inhibitory effect on the adipogenic differentiation of human adipose-derived mesenchymal stem cells. Stem Cell Rev 2018; 14: 901-914.

10. Tatullo M, Spagnuolo G, Codispoti B, et al. Pla-based mineral-doped scaffolds seeded with human periapical cyst-derived mscs: A promising tool for regenerative healing in dentistry. Materials (Basel) 2019; 12 .

11. Tatullo M, Codispoti B, Pacifici A, et al. Potential use of human periapical cyst-mesenchymal stem cells (hpcy-mscs) as a novel stem cell source for regenerative medicine applications. Front Cell Dev Biol 2017; 5: 103.

12. Aulino P, Costa A, Chiaravalloti E, et al. Muscle extracellular matrix scaffold is a multipotent environment. Int J Med Sci 2015; 12: 336-340.

13. Han I, Kwon BS, Park HK, et al. Differentiation potential of mesenchymal stem cells is related to their intrinsic mechanical properties. Int Neurourol J 2017; 21: S24-31.

14. Gao F, Chiu SM, Motan DA, et al. Mesenchymal stem cells and immunomodulation: Current status and future prospects. Cell Death Dis 2016; 7: e2062.

15. Wang LT, Ting CH, Yen ML, et al. Human mesenchymal stem cells (mscs) for treatment towards immune- and inflammation-mediated diseases: Review of current clinical trials. J Biomed Sci 2016; 23: 76.

16. Guicciardi ME, Gores GJ, et al. Apoptosis: A mechanism of acute and chronic liver injury. Gut 2005; 54: 1024-1033.
17. Inchingolo $\mathrm{F}$, Tatullo $\mathrm{M}$, Abenavoli FM, et al. Oral piercing and oral diseases: a short time retrospective study. Int J Med Sci 2011; 8: 649-652.

18. Kang PM, Izumo S. Apoptosis in heart: Basic mechanisms and implications in cardiovascular diseases. Trends Mol Med 2003; 9: 177-182.

19. Sharma R, Anker SD. Cytokines, apoptosis and cachexia: The potential for tnf antagonism. Int J Cardiol 2002; 85: 161-171.

20. Favaloro B, Allocati N, Graziano V, et al. Role of apoptosis in disease. Aging (Albany NY) 2012; 4: 330-349.

21. Rohn TT. The role of caspases in alzheimer's disease; potential novel therapeutic opportunities. Apoptosis 2010; 15: 1403-1409.

22. Samantaray S, Knaryan VH, Guyton MK, et al. The parkinsonian neurotoxin rotenone activates calpain and caspase- 3 leading to motoneuron degeneration in spinal cord of lewis rats. Neuroscience 2007; 146: 741-755.

23. Pasinelli P, Houseweart MK, Brown RH, et al. Caspase-1 and -3 are sequentially activated in motor neuron death in $\mathrm{cu}_{\mathrm{zn}} \mathrm{zuperoxide}$ dismutase-mediated familial amyotrophic lateral sclerosis. Proc Natl Acad Sci U S A 2000; 97: 13901-13906.

24. Nagata S. Apoptosis and autoimmune diseases. IUBMB Life 2006; 58: 358-362.

25. Greenhalgh DG. The role of apoptosis in wound healing. Int J Biochem Cell Biol 1998; 30: 1019-1030.

26. Brown DL, Kao WW, Greenhalgh DG. Apoptosis down-regulates inflammation under the advancing epithelial wound edge: Delayed patterns in diabetes and improvement with topical growth factors. Surgery 1997; 121: 372-380.

27. Ohta $\mathrm{H}$, Yatomi $\mathrm{Y}$, Sweeney EA, et al. A possible role of sphingosine in induction of apoptosis by tumor necrosis factor-alpha in human neutrophils. FEBS Lett 1994; 355: 267-270.

28. Tatullo M, Marrelli M, Amantea M, et al. Bioimpedance Detection of Oral Lichen Planus Used as Preneoplastic Model. J Clin Invest 1994; 93: 2206-2214.

29. Ozaki N, Ishizaki M, Ghazizadeh M, et al. Apoptosis mediates decrease in cellularity during the regression of arthus reaction in cornea. Br J Ophthalmol 2001; 85: 613-618.

30. Green DR. A myc-induced apoptosis pathway surfaces. Science 1997; 278: 1246-1247.

31. Granstein RD, Rook A, Flotte TJ, et al. A controlled trial of intralesional recombinant interferon-gamma in the treatment of keloidal scarring. Clinical and histologic findings. Arch Dermatol 1990; 126: 1295-1302.

32. Suzanne M, Steller H. Shaping organisms with apoptosis. Cell Death Differ 2013; 20: 669-675.

33. Hector S, Rehm M, Schmid J, et al. Clinical application of a systems model of apoptosis execution for the prediction of colorectal cancer therapy responses and personalisation of therapy. Gut 2012; 61: 725-733. 
34. Koren E, Yosefzon Y, Ankawa R, et al. Arts mediates apoptosis and regeneration of the intestinal stem cell niche. Nat Commun 2018; 9: 4582.

35. Fuchs $Y$, Brown $S$, Gorenc $T$, et al. Sept 4 /arts regulates stem cell apoptosis and skin regeneration. Science 2013; 341: 286-289.

36. Fuchs Y, Steller H. Live to die another way: Modes of programmed cell death and the signals emanating from dying cells. Nat Rev Mol Cell Biol 2015; 16: 329-344.

37. Perez-Garijo A, Fuchs Y, Steller H. Apoptotic cells can induce non-autonomous apoptosis through the tnf pathway. Elife 2013; 2: e01004.

38. Yuan J. Neuroprotective strategies targeting apoptotic and necrotic cell death for stroke. Apoptosis 2009; 14: 469-477.

39. Ryoo HD, Bergmann A. The role of apoptosis-induced proliferation for regeneration and cancer. Cold Spring Harb Perspect Biol 2012; 4: a008797.

40. Fan Y, Wang S, Hernandez J, et al. Genetic models of apoptosis-induced proliferation decipher activation of jnk and identify a requirement of egfr signaling for tissue regenerative responses in drosophila. PLoS Genet 2014; 10 : e1004131.

41. Fan Y, Bergmann A. Apoptosis-induced compensatory proliferation. The cell is dead. Long live the cell! Trends Cell Biol 2008; 18: 467-473.

42. Love NR, Chen Y, Ishibashi S, et al. Amputation-induced reactive oxygen species are required for successful xenopus tadpole tail regeneration. Nat Cell Biol 2013; 15: 222-228.

43. Chera S, Ghila L, Dobretz K, et al. Apoptotic cells provide an unexpected source of wnt3 signaling to drive hydra head regeneration. Dev Cell 2009; 17: 279-289.

44. Tatullo M, Simone GM, Tarullo F, et al. Antioxidant and antitumor activity of a bioactive polyphenolic fraction isolated from the brewing process. Sci Rep 2016; 6: 36042

45. Tatullo M, Gentile S, Paduano F, et al. Crosstalk between oral and general health status in e-smokers. Medicine (Baltimore) 2016; 95: e5589.

46. Hansen BH, Hallmann A, Altin D, et al. Acute hydrogen peroxide (h2o2) exposure does not cause oxidative stress in late-copepodite stage of calanus finmarchicus. J Toxicol Environ Health A 2017; 80: 820-829.

47. Wei H, Li Z, Hu S, et al. Apoptosis of mesenchymal stem cells induced by hydrogen peroxide concerns both endoplasmic reticulum stress and mitochondrial death pathway through regulation of caspases, p38 and jnk. J Cell Biochem 2010; 111:967-978.

48. Fortunato L, Barone S, Bennardo F, et al. Management of facial pyoderma gangrenosum using platelet-rich fibrin: A technical report. J Oral Maxillofac Surg 2018; 76: 1460-1463.

49. Lo Muzio L, Bucci P, Carile F, et al. Prosthetic rehabilitation of a child affected from anhydrotic ectodermal dysplasia: A case report. J Contemp Dent Pract 2005; 6: 120-126.

50. De Santis R, Gloria A, Russo T, et al. Reverse engineering of mandible and prosthetic framework: Effect of titanium implants in conjunction with titanium milled full arch bridge prostheses on the biomechanics of the mandible. J Biomech 2014; 47: 3825-3829.

51. Giudice A, Bennardo F, Barone S, et al. Can autofluorescence guide surgeons in the treatment of medication-related osteonecrosis of the jaw? A prospective feasibility study. J Oral Maxillofac Surg 2018; 76: 982-995.

52. Janzen V, Fleming HE, Riedt $\mathrm{T}$, et al. Hematopoietic stem cell responsiveness to exogenous signals is limited by caspase-3. Cell Stem Cell 2008; 2: 584-594.

53. Fujita J, Crane AM, Souza MK, et al. Caspase activity mediates the differentiation of embryonic stem cells. Cell Stem Cell 2008; 2: 595-601.

54. Miura M, Chen XD, Allen MR, et al. A crucial role of caspase-3 in osteogenic differentiation of bone marrow stromal stem cells. J Clin Invest 2004; 114: 1704-1713.

55. Yosefzon Y, Soteriou D, Feldman A, et al. Caspase-3 regulates yap-dependent cell proliferation and organ size. Mol Cell 2018; 70: 573-587 e574.

56. Galleu A, Riffo-Vasquez Y, Trento C, et al. Apoptosis in mesenchymal stromal cells induces in vivo recipient-mediated immunomodulation. Sci Transl Med 2017; 9 .

57. Codispoti B, Marrelli M, Paduano F, et al. Nanometric bio-banked msc-derived exosome (nanobiome) as a novel approach to regenerative medicine. J Clin Med 2018; 7.

58. Liu D, Kou X, Chen C, et al. Circulating apoptotic bodies maintain mesenchymal stem cell homeostasis and ameliorate osteopenia via transferring multiple cellular factors. Cell Res 2018; 28: 918-933.

59. Deng B, Jiang H, Zeng K, et al. Removal from adherent culture contributes to apoptosis in human bone marrow mesenchymal stem cells. Mol Med Rep 2017; 15: 3499-3506.

60. Codispoti B, Rinaldo N, Chiarella E, et al. Recombinant tat-bmi-1 fusion protein induces ex vivo expansion of human umbilical cord blood-derived hematopoietic stem cells. Oncotarget 2017; 8: 43782-43798.

61. Schafer M, Werner S. Cancer as an overhealing wound: An old hypothesis revisited. Nat Rev Mol Cell Biol 2008; 9: 628-638.

62. Soteriou D, Fuchs Y. A matter of life and death: Stem cell survival in tissue regeneration and tumour formation. Nat Rev Cancer 2018; 18: 187-201.

63. Ichim G, Tait SW. A fate worse than death: Apoptosis as an oncogenic process. Nat Rev Cancer 2016; 16: 539-548.

64. Najafi M, Fardid R, Hadadi G, et al. The mechanisms of radiation-induced bystander effect. J Biomed Phys Eng 2014; 4: 163-172.

65. Nguyen-Chi M, Laplace-Builhe B, Travnickova J, et al. Tnf signaling and macrophages govern fin regeneration in zebrafish larvae. Cell Death Dis 2017; 8: e2979. 